\title{
EXTRADURAL SPINAL CORD HEMANGIOBLASTOMA: A CASE REPORT AND LITERATURE REVIEW
}

\author{
HEMANGIOBLASTOMA EXTRADURAL MEDULAR: RELATO DE CASO E REVISÃO \\ DE LITERATURA
}

\section{HEMANGIOBLASTOMA EXTRADURAL DE LA MÉDULA ESPINAL: INFORME DE UN CASO Y REVISIÓN DE LA LITERATURA}

\author{
Nikolay A. Konovalov, ${ }^{1}$ Stanislav U. Timonin, ${ }^{2}$ Lyudmila V. Shishina, ${ }^{3}$ Anton G. Nazarenko, ${ }^{2}$ Dmitri A. Asyutin, ${ }^{2}$ Roman O. Onoprienko, ${ }^{2}$ \\ Vasyli V. Korolishin, ${ }^{2}$ Bahromhon A. Zakirov, ${ }^{2}$ Maria M. Martynova, ${ }^{2}$ Stanislay V. Kaprovoy, ${ }^{2}$ Arthur L. Pogosyan, ${ }^{2}$ Albert A. Batyrov, ${ }^{2}$ \\ Islam U. Cherkiev, ${ }^{2}$ Evgeni S. BrenyK²
}

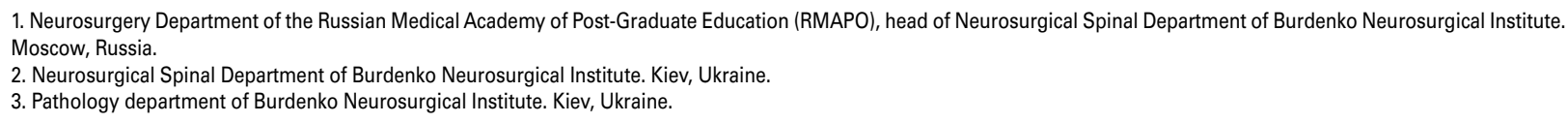

\begin{abstract}
Objective: Hemangioblastoma is a rare vascular sporadically occurring CNS tumor that can be associated with von Hippel-Lindau disease. Hemangioblastomas account for 2-6\% of all spinal cord neoplasms and rank third among intramedullary space-occupying lesions. Methods: This was the first time in our practice that we had dealt with paravertebral hemangioblastoma with the sandglass growth pattern. The world literature describes only 3 case of a tumor with this growth pattern. Surgical and diagnostic aspects of patient treatment are considered. Results: During the operation, we adhered to the following stages: localization of the feeding vessel and of the poles of the tumor, surface dissection of the tumor, en bloc resection of the tumor, and hemostasis of the tumor cavity. Conclusions: Hemangioblastoma of extradural localization is a very rare pathology. However, when MRI signs characteristic of a vascular lesion are identified, it is necessary to carry out additional examinations, which may include CT perfusion study and, if required, selective angiography. Level of Evidence 5; Case report.
\end{abstract}

Keywords: Spinal cord tumor; Hemangioblastoma; Spine; Neurosurgery.

\section{RESUMO}

Objetivos: Hemangioblastoma é um tumor vascular raro do SNC, que ocorre esporadicamente e pode ser associada à doença de Von Hippel-Lindau. Hemangioblastomas são responsáveis por 2-6\% de todas as neoplasias da medula espinal e na terceira posição entre lesões, ocupando espaço intramedulares da medula espinal. Métodos: Foi a primeira vez em nossa prática que lidamos com hemangioblastoma paravertebral com o padrão de crescimento ampulheta. As fontes da literatura mundial descrevem apenas 3 casos de um tumor com esse padrão de crescimento. Aspectos cirúrgicos e diagnósticos de tratamentos do paciente são considerados. Resultados: Durante a operação, aderiu-se às seguintes fases: o recipiente de alimentação foi encontrado, os pólos do tumor foram encontrados, a dissecação da superfície do tumor foi feita, o tumor foi removido por um único bloco e a hemostasia da cavidade do tumor foi realizada. Conclusões: Hemangioblastoma de localização extradural é uma patologia muito rara, no entanto, quando sinais de MRI característicos de uma lesão vascular são identificados, o que é necessário para levar a cabo um exame suplementar, o qual pode incluir o estudo de perfusão CT e, se necessário, angiografia seletiva. Nível de Evidência V; Relato de caso.

Descritores: Tumor da medula espinhal; Hemangioblatoma; Coluna vertebral; Neurocirurgia.

\section{RESUMEN}

Objetivo: El hemangioblastoma es un tumor vascular raro del SNC que ocurre esporádicamente y que puede asociarse con la enfermedad de von Hippel-Lindau. Los hemangioblastomas representan el 2\%-6\% de todas las neoplasias de la médula espinal y están en el tercer lugar entre las lesiones intramedulares que ocupan espacio. Métodos: Esta fue la primera vez en nuestra práctica que tratamos el hemangioblastoma paravertebral con patrón de crecimiento de reloj de arena. La literatura mundial describe solo tres casos de un tumor con este patrón de crecimiento. Se consideran aspectos quirúrgicos y de diagnóstico del tratamiento del paciente. Resultados: Durante la operación, elegimos las siguientes etapas: localización del vaso de irrigación y de los polos del tumor, disección superficial del tumor resección en bloque del tumor y hemostasia de la cavidad tumoral. Conclusiones: El hemangioblastoma de localización extradural es una patología muy rara. Sin embargo, cuando se identifican signos característicos de lesión vascular en la $R M$, es necesario realizar exámenes adicionales, que pueden incluir estudio de perfusión por TC y, si es necesario, una angiografía selectiva. Nivel de Evidencia V; Reporte de caso.

Descriptores: Neoplasias de la médula espinal; Hemangioblastoma; Columna vertebral; Neurocirugia. 


\section{INTRODUCTION}

Hemangioblastoma is a rare vascular sporadically occurring CNS tumor that can be associated with von Hippel-Lindau disease. Hemangioblastomas account for 2-6\% of all spinal cord neoplasms and rank third among intramedullary space-occupying lesions of the spinal cord. This was the first time in our practice that we had dealt with paravertebral hemangioblastoma with the sandglass growth pattern. The world literature describes only 3 case of a tumor with this growth pattern.

\section{Clinical Case}

Patient N, 56 y.o., was admitted to the Burdenko Scientific Research Institute of Neurosurgery on September 3, 2014 with complaints of pain in the lumbosacral region irradiating to the left leg, as well as sensation disorders manifesting as hypostasis on the posterior surface of the left thigh and lower leg. It is follows from the anamnesis that the back pain had disturbed the patient for a long time, gradually intensifying until eventually, the pain syndrome became permanent. Multiple drug therapy courses were used to treat spinal osteochondrosis. No improvements in the patient's state after therapy were noted. Since 2006, the pain has intensified, starting to occur at rest, when sitting and lying down. In August 2013, the pain became particularly intense, and no significant effects of conservative therapy were achieved. In view of this, MRI study of the lumbosacral spine was performed, revealing an extradural space-occupying lesion with paravertebral proliferation at the level of the L4-L5 vertebrae in the left intervertebral foramen (Figure 1). The neoplasm was oval in shape, with dimensions: 16×25×10 mm. Spinal angiography was performed with contrast in the space-occupying lesion vasculature at the L4 vertebra level. The patient was hospitalized in the neurosurgical department nearest to the place of residence for tumor resection. An attempt to resect the tumor failed. Findings of the collected tissue histological study corresponded to ganglioneuroma

\section{Surgery}

The patient was placed in the prone position on the operating table, under complex anesthesia with endotracheal lung ventilation. The level of the tumor localization was determined using an intraoperative O-arm (Medtronic) CT scanner. The images were taken in the lateral and frontal planes in the 2D mode. A paramedian skin incision was performed on the left, a few centimeters from the scar from the previous operation. The tumor was accessed using an operating microscope and a Caspar retractor. The use of this expander helped minimize trauma to the surrounding tissues. Hemilaminectomy was performed on the left at the level of the L4 vertebral arch, using microsurgical instruments and a high-speed Zimmer drill. The $3 \times 2 \mathrm{~cm}$ prolate orange tumor was visualized. The tumor was located in the

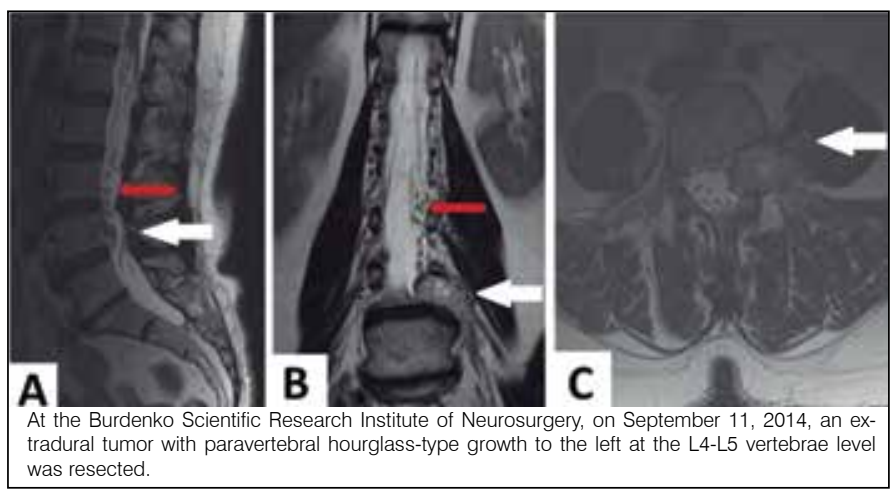

Figure 1. Hemangioblastoma of the $L 4$ nerve root. A series of MRI scans performed in the sagittal, frontal and axial projections in the T2 mode (A, B, C) showed an extradural, hypo-intensive space-occupying lesion at the level of the L4-L5 vertebrae with hyperintense foci and paravertebral growth to the left of the dumbbell type. In the sagittal projection (A) the intense tumor vasculature is clearly seen, which corresponds to the multiple zones of the hypointense signal in the T2 mode. (red arrow) intervertebral opening L4-L5 and resembled a neurinoma in form. The extradural part of the $\mathrm{L} 4$ root on the left was determined as the growth zone. During detachment of the tumor along the perimeter, a large vessel feeding the tumor was detected. This vessel was coagulated and incised. Ligation was applied to the proximal part of the tumor and the root, after which the tumor and the nerve root were coagulated and excised en bloc (Figure.2). A hemostatic material was placed in the bed of the excised tumor. The wound was then closed by the standard procedure.

In the postsurgical period, regression of the pain syndrome was noted. The patient was activated on the first day after the surgery. Seven days after the operation, the patient was discharged in a satisfactory condition. Histological diagnosis: Hemangioblastoma. In the 3 months after the surgery, a control MRI study was performed (Figure 3).

\section{Histological characteristics of the tumor}

Histological examination confirmed the macroscopic diagnosis of hemangioblastoma. The tumor structure consists of two types of cells: stromal cells with an optically empty cytoplasm, and a large number of hemangioblasts (Figure 4).
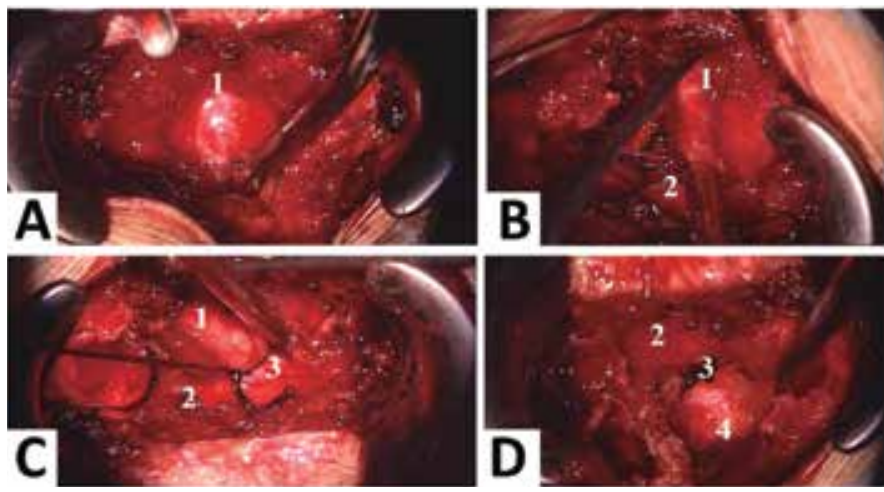

Figure 2. Stages of the surgery: $A$ and $B$ - detachment and mobilization of a solid part of the tumor, B - ligation of the $L 4$ root tumor cervix, D - excision of the tumor with the root. 1- solid part, 2 - L4 root, 3 - root sleeve, 4 - tumor bed.
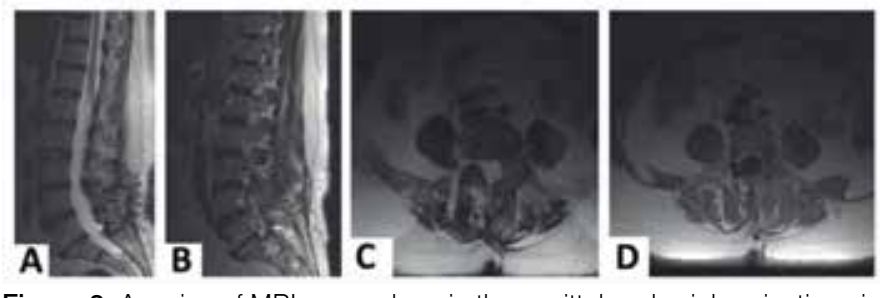

Figure 3. A series of MRI scans done in the sagittal and axial projections in the T2 mode (, , B , C, D) shows the state after radical excision of hemangioblastoma

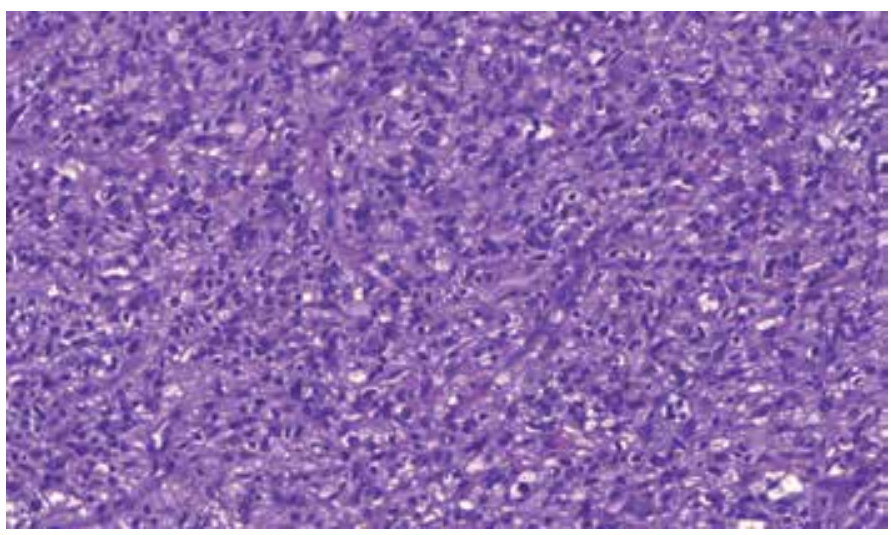

Figure 4. Hemangioblastoma, staining with hematoxylin and eosin, X200 magnification. 
The tumor (Figure 5 - on the left, marked with a red arrow) was surrounded by a thin layer of a fibrous tissue with closely adjoining nervous tissue fragments and ganglion cells congestion (on the right, marked with a green arrow).

During the study, an adjacent nerve trunk was detected, Pluta, R.M. reports the same histological findings (Figure 6). ${ }^{2}$

\section{DISCUSSION}

Hemangioblastoma of the spinal cord belongs to a class of highly vascularized tumors with predominant intramedullary localization. In our case, the tumor was situated paravertebrally, demonstrated the sandglass growth pattern, and had no connection with the dura mater. We performed a world literature search and found case studies of three patients with a similar localization of spaceoccupying lesions No. 1, 2, 3. Below is the table with these patients' data, clinical status and the surgical treatment outcome (Table 1).

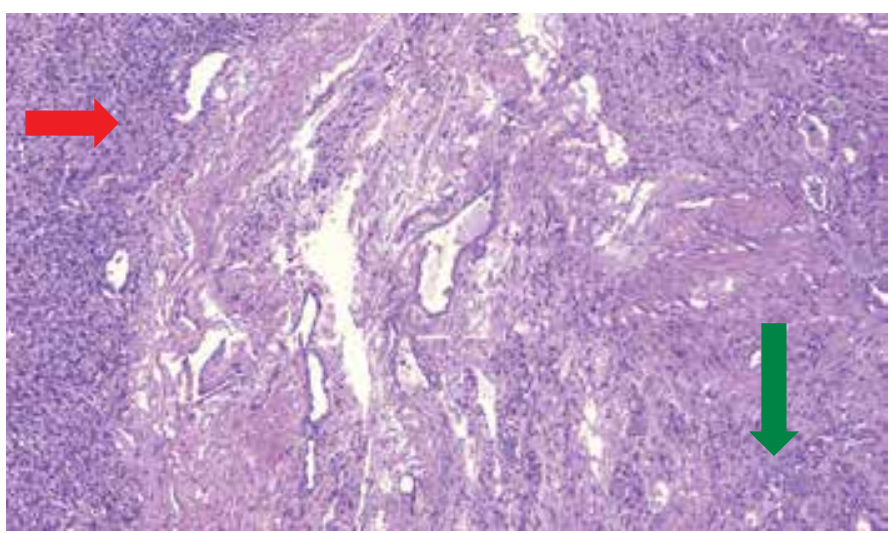

Figure 5. Hemangioblastoma and accumulation of ganglion cells, staining with hematoxylin and eosin, X100 magnification.

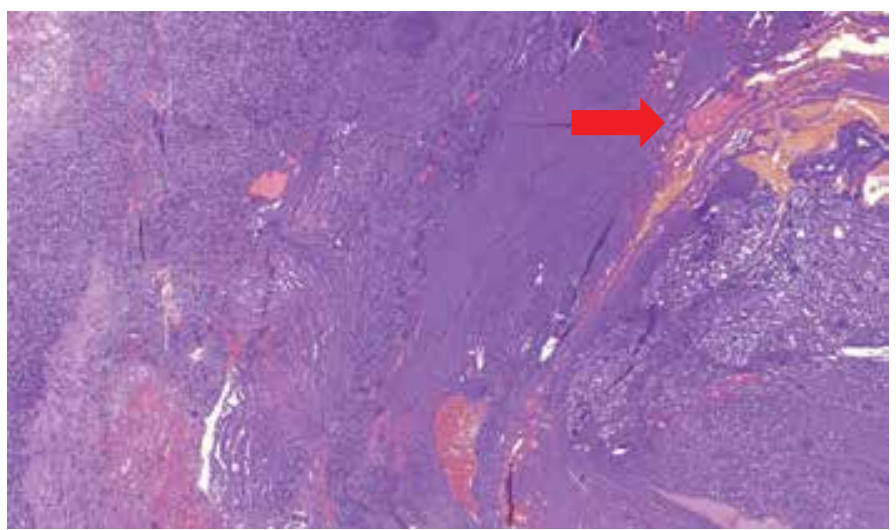

Figure 6. Hemangioblastoma and adjacent nerve column, staining with hematoxylin and eosin, X50 magnification.

\section{Clinical pattern}

In Case Study No.1, an acute onset of the disease was noted with a severe pain syndrome developing for 2 weeks, after which the patient was hospitalized in a neurosurgical hospital. In the remaining Case Studies No. 2 and 3 as well as in the case study of our patient, a long case history was observed lasting from 2 to 20 years. The tumor manifested itself as radiculopathy in the form of a pain syndrome in the lumbosacral spine, irradiating to the leg, accompanied by sensation disorders. In Case Study No. 2, pelvic organ dysfunction was recorded. Such symptoms are possible with any tumor in this location, therefore in the primary examination stage, pelvic organ dysfunction is not a specific criterion for radicular hemangioblastoma.

\section{X-ray study}

In Case Studies No.3 and 4 at the preoperative stage, according to the MRI study, a presumptive diagnosis was established: neurogenic tumor - neurinoma (schwannoma) of the spinal root. The patient with von Hippel-Lindau disease had multiple hemangioblastomas of the central nervous system. The authors therefore suggest performing the correct histological diagnosis at the pre-surgical level. Our patient was admitted to the clinic with a diagnosis of gangioneuroma of the L4 root with paravertebral growth, since after the first surgery, a corresponding histological diagnosis was established.

After our analysis of the X-ray data, the following conclusions were made. First, all studies should be enhanced by a contrast agent. Secondly, detection of pathologically enlarged convoluted vessels within the spinal canal around the lesion is a pathognomonic sign of hemangioblastoma. The vessels are best visualized in the T2 mode. Thirdly, a solid component of the tumor has a hypo- or iso-intensive MR signal in the T1 mode, and the cystic cavities have a signal similar to the CSF in the T1 and T2 modes, or a more intense signal in the T2 mode. Identification of at least one of the listed MRI signs suggests a vascular pattern of the tumor, and selective angiography may be indicated.

\section{Peculiarities of extradural hemangioblastoma resection}

Extramedullary hemangioblastoma is a sufficiently rare pathology, therefore there is no standard for such tumor resection. We use the following principles for the tumor resection: first, it is necessary to detach the feeding vessel; in hemangioblastomas this vessel is the radicular artery, running parallel to the radix at the level of the tumor location. The second stage is to separate the tumoral poles, while preserving the enlarged drainage veins of the tumor. Manipulation inside the tumor capsule is dangerous due to the possibility of severe bleeding, which is usually difficult to control and can completely obscure the entire field of vision. Hemangioblastomas are encapsulated and can be easily separated from surrounding tissues. After excision of the tumor, a crater is formed - the tumor bed, which is examined to stop bleeding from small vessels. Hemostasis in this situation must be achieved with the help of hemostatic materials, abstaining from use of bipolar coagulation.

This was the first instance, in our practice, of a hemangioblastoma with extradural location. Therefore, we used the microsurgical

Table 1. Review of publications describing treatment of radicular hemangioblastomas of the spinal cord.

\begin{tabular}{|c|c|c|c|c|c|c|c|c|c|c|c|}
\hline $\begin{array}{c}\text { Author and } \\
\text { year }\end{array}$ & $\begin{array}{c}\text { Case study } \\
\text { number }\end{array}$ & Sex & $\begin{array}{c}\text { Age } \\
\text { (y.o.) }\end{array}$ & $\begin{array}{c}\text { Anamnes } \\
\text { morbi } \\
\text { (month) }\end{array}$ & Localization & \begin{tabular}{|c|} 
VHL (von \\
Hippel- \\
Lindau) \\
\end{tabular} & $\begin{array}{c}\text { Presumptive } \\
\text { diagnosis before } \\
\text { surgery }\end{array}$ & $\begin{array}{c}\text { AG with } \\
\text { embolization }\end{array}$ & $\begin{array}{l}\text { Clinical } \\
\text { pattern }\end{array}$ & $\begin{array}{c}\text { Catamnesis } \\
\text { (months) }\end{array}$ & $\begin{array}{l}\text { Results of } \\
\text { treatment }\end{array}$ \\
\hline $\begin{array}{l}\text { Ryszard M. } \\
\text { Pluta } 2003 \\
\end{array}$ & 1 & $\mathrm{~F}$ & 38 & 120 & $\begin{array}{c}\text { ED S1-S2 on } \\
\text { the left. }\end{array}$ & + & Hemangioblastoma & + & \begin{tabular}{|l} 
RPS on \\
S1-2, SN.
\end{tabular} & 12 & $\begin{array}{c}\text { RPS } \\
\text { regression }\end{array}$ \\
\hline $\begin{array}{c}\text { María } \\
\text { Román-de } \\
\text { Aragón } \\
2014 \\
\end{array}$ & 3 & M & 48 & 1 & $\begin{array}{c}\text { ED-SG L4 on } \\
\text { the right. }\end{array}$ & - & neuroma & + & $\begin{array}{l}\text { PS, RPS, } \\
\text { SD, PODS }\end{array}$ & 36 & $\begin{array}{l}\text { PS, RPS, } \\
\text { SD, PODF } \\
\text { regression }\end{array}$ \\
\hline
\end{tabular}

ED - extradural location, SG - dumbbells type of tumor, PS - pain syndrome, RPS - radicular pain syndrome, SD - sensation disorders, MD - motor disorders, PODF - pelvic organs dysfunction. 
resection technique, according to the principle of the sandglass tumor growth pattern. Unfortunately, we did not perform embolization of the feeding vessel of the tumor prior to surgery. Therefore, when the paravertebral part of the lesion extending beyond the intervertebral foramen was detached, the radicular artery feeding the tumor started bleeding. The bleeding was successfully stopped by bipolar coagulation. In the next stage, we detached a portion of the tumor adjacent to the tumor sac and applied a ligature to the root making up the stroma of the tumor, to prevent liquorrhea from emerging from the root sleeve. In our case, it was not possible to detach the hemangioblastoma from the nerve root, as the two were closely fused. Therefore, the hemangioblastoma was excised together with the L4 root. Despite the root excision, no negative symptoms were noted, such as intensification of the muscular weakness of the left leg.

\section{Outcomes of surgical treatment}

The result of surgical treatment in the cases cited in the literature is total resection of the tumor in this localization, but there may be a slight neurological deficit, since the tumor is usually resected with the root from which it originates.

\section{CONCLUSIONS}

Hemangioblastoma of extradural localization is a very rare pathology. However, when MRI signs characteristic of a vascular lesion are identified, it is necessary to carry out an additional examination, which may include CT perfusion study and, if required, selective angiography. If hemangioblastoma with clearly differentiated feeding vessels is visualized, embolization is necessary, to reduce risks of intraoperative bleeding.

All authors declare no potential conflict of interest related to this article.

CONTRIBUTION OF THE AUTHORS: Each author made significant individual contributions to this manuscript. NAK (0000-0003-0824-1848) ${ }^{\star}$ and SUT were the main contributors in the drafting of the manuscript. LVS (0000-0001-7045-7223)* performed the histological analyses. AGN (0000-0002-3726-5761)*, DAA, ROO performed the surgery, VVK (0000-0001-5777-6561)* followed up the patients and BAZ gathered clinical data. MMM (0000-0002-2259-3842)*, SVK, and ALP evaluated the data from the statistical analysis. AAB, IUC, ESB performed the literature search and review of the manuscript, and contributed to the intellectual concept of the study. ${ }^{*}$ ORCID (Open Researcher and Contributor ID).

\section{REFERENCES}

1. Mehta GU, Asthagiri AR, Bakhtian KD, Auh S, Oldfield EH, Lonser RR. Functional outcome after resection of spinal cord hemangioblastomas associated with von HippelLindau disease. J Neurosurg Spine. 2010;12(3):233-42.

2. Pluta RM, Wait SD, Butman JA, Leppig KA, Vortmeyer AO, Oldfield EH, Lonser RR. Sacral hemangioblastoma in a patient with von Hippel-Lindau disease. Case report and review of the literature. Neurosurg Focus. 2003;15(2):E11.
3. Chazono M, Shiba R, Funasaki H, Soshi S, Hattori A, Fujii K. Hemangioblastoma of the L-5 nerve root. Case illustration. J Neurosurg Spine. 1999;90(1):160.

4. Román-de Aragón M, MárquezT, Isla A, Gómez-de la Riva Á. Hemangioblastoma radicular extraforaminal de la raíz L4 derecha. Neurocirugía. 2014;25(6):286-9.

5. Kornienko VN, Pronin IN. Diagnostic neuroradiology. Berlin: Springer-Verlag Berlin Heidelberg; 2009. 